\title{
APPEARANCE AND FREQUENCE OF FUNGI ON ALFALFA SEED IN SERBIA
}

\section{T. Vasić ${ }^{1}$, S. Anđelković ${ }^{1}$, S. Živković ${ }^{2}$, B. Anđelković ${ }^{1}$, D. Terzić ${ }^{1}$, J. Milenković ${ }^{1}$}

\author{
${ }^{1}$ Institute for Forage Crops, Kruševac, Globoder, 37251 Kruševac, Republic of Serbia \\ ${ }^{2}$ Faculty of Agriculture, Belgrade-Serbia, Nemanjina 6, 11080 Belgrade, Republic of Serbia \\ Corresponding author: tanja.vasic@ikbks.com \\ Original scientific paper
}

Abstract: Alfalfa is one of the most significant forage crops in Serbia, and is known colloquially as "the queen of forage crops" due its significant role in livestock nutrition. Production of high quality forage and seed is of high importance for animal husbandry in Serbia. Fungi infections decrease seed quality which has influence on yield and quality of forage and on period of alfalfa utilization. Samples of alfalfa seed from Middle Banat, Danube region, Niš and Šumadija area were examined. Samples were taken from two alfalfa cultivars K-22 and K-28. Based on the examinations of appearance of fungi on the alfalfa seed, following fungi were determined: Fusarium spp., Alternaria spp., Stemphylium spp., Epiccocum spp., Nigrospora spp., Rhizopus spp., Mucor spp., Aspergillus spp. and Penicillium spp. Primary species were from genera Fusarium and Alternaria, and other species were represented in different percentages.

Key words: seed, fungi, alfalfa

\section{Introduction}

A large number of pathogens that cause diseases of root and above-ground parts of alfalfa are usually transmitted by seed. Apart from pathogenic microorganisms, often are saprophytic microorganisms on alfalfa seed. For these reasons, especially when it comes to perennials, such as alfalfa, it is important to use healthy seed for sowing. The most common pathogenic and saprophytic microorganisms on alfalfa seed are fungi and less common are bacteria and viruses. Some pathogenic bacteria and fungi maintain vitality in the soil and the plant remains for years, and are a source of infection for the planted seed and alfalfa seedlings.

In Serbia, over ten different types of fungi were isolated from alfalfa and red clover seed, of which most of the genera: Alternaria and Fusarium (Krnjaja et al., 2003, 2004). 
Due to its importance in the implementation of healthy seeds during the establishing of perennial forage legumes, it is important to study the occurrence and intensity of fungal diseases on alfalfa seeds.

\section{Materials and Methods}

Research was conducted in the Laboratory for Microbiology of the Institute for Forage Crops in Kruševac. As a starting material two varieties of alfalfa were used: K-22 and K-28. The samples originated from the harvest in 2009. Sampling was conducted during period of February-March 2010. Plant material was derived from areas of Serbia (Central Banat district, the Danube district, Niš district, Šumadija district).

Several samples were taken from each district and 100 seeds were used per sample in 10 Petri dishes, 10 seeds per Petri dish.

In the method A, the seeds were sterilized by the method of Graham et al. (1976). Seeds were surface-sterilized by immersing in 0.26\% sodium hypochlorite for five minutes and then dried. Ten seeds were placed in each Petri dish with on corn meal agar medium (CMA). Dishes were kept at room temperature for 10 days.

In the method B, the seeds were surface sterilized by the method of Chi et al. (1964). Seeds were surface disinfected in $7 \%$ sodium hypochlorite $(\mathrm{NaOCl})$ for 5 minutes, rinsed in sterile water and dried at room temperature. Then the seeds were put on potato dextrose medium (PDA).

After ten days, the colonies were developed around the seed, and each colony was separately examined under the microscope for future identification and some of the cultures were transferred to two media: potato-dextrose medium (PDA) and the medium prepared from water and agar (WA).

Determination of Fusarium species was conducted based on macroscopic and microscopic traits on the PDA and water-agar medium (WA) according to the methods of Nelson et al. (1983) and Burgess et al. (1994), while other genera were determined by the method of Watanabe et al. (1994).

\section{Results}

Microscopic study of colonies of fungi, isolated from alfalfa seed, showed varying degrees of infection, at different times and way of seed sterilization (Table 1). There was a significant difference in health status of seed using methods A and B. 
Table 1. The intensity of alfalfa seed infection

\begin{tabular}{|c|c|c|c|c|}
\hline \multirow{3}{*}{ Cultivar } & \multicolumn{4}{|c|}{ Intentsity of seed infection (\%) } \\
\hline & \multicolumn{2}{|l|}{ Methods A } & \multicolumn{2}{|l|}{ Methods B } \\
\hline & Fungus type & $\%$ & Fungus type & $\%$ \\
\hline \multirow{13}{*}{$\mathrm{K}-22$} & Alternaria spp. & 25.2 & Alternaria spp. & 10.2 \\
\hline & Aspergillus spp. & 2.8 & Aspergillus spp. & 2.0 \\
\hline & Cladosporium spp. & 3.8 & Cladosporium spp. & - \\
\hline & Epiccocum spp. & 1.8 & Epiccocum spp. & - \\
\hline & Fusarium spp. & 26.6 & Fusarium spp. & 12.1 \\
\hline & Mucor spp. & 4.6 & Mucor spp. & 3.0 \\
\hline & Nigrospora spp. & 3.5 & Nigrospora spp. & - \\
\hline & Penicillium spp. & 3.6 & Penicilliium spp. & 1.0 \\
\hline & Rhizoctonia spp. & 0.5 & Rhizoctonia spp. & - \\
\hline & Rhizopus spp. & 4.1 & Rhizopus spp. & 3.0 \\
\hline & Sclerotinia spp. & 0.9 & Sclerotinia spp. & - \\
\hline & Stemphylium spp. & 14.7 & Stemphylium spp. & - \\
\hline & Trichoderma spp. & 1.8 & Trichoderma spp. & - \\
\hline \multirow{13}{*}{ K-28 } & Alternaria spp. & 25.0 & Alternaria spp. & 12.0 \\
\hline & Aspergillus spp. & 9.0 & Aspergillus spp. & - \\
\hline & Cladosporium spp. & 2.9 & Cladosporium spp. & - \\
\hline & Epiccocum spp. & 0.8 & Epiccocum spp. & - \\
\hline & Fusarium spp. & 28.8 & Fusarium spp. & 15.0 \\
\hline & Mucor spp. & 7.5 & Mucor spp. & 1.0 \\
\hline & Nigrospora spp. & 4.8 & Nigrospora spp. & - \\
\hline & Penicillium spp. & 2.9 & Penicilliium spp. & 1.1 \\
\hline & Rhizoctonia spp. & - & Rhizoctonia spp. & - \\
\hline & Rhizopus spp. & 5.5 & Rhizopus spp. & 0.5 \\
\hline & Sclerotinia spp. & 2.7 & Sclerotinia spp. & - \\
\hline & Stemphylium spp. & 7.3 & Stemphylium spp. & - \\
\hline & Trichoderma spp. & 1.8 & Trichoderma spp. & - \\
\hline
\end{tabular}

Based on the obtained results we can conclude that different time and way of sterilization affect the degree of seed infection.

The method A involves a shorter time of sterilization, as evidenced by the number of fungi, where total of thirteen genera were isolated. There is a difference in the percentage of representation of fungi in K-22 and K-28. The most numerous fungi of the genus Fusarium (26.6\%) in the variety K-22, while in K-28 was $28.8 \%$ and Alternaria (25\%) for the variety K-22 while for K-28 was $25.2 \%$. Stemphylium spp. with $14.7 \%$ represented in the variety $\mathrm{K}-22$ and in K-28 was represented with $7.3 \%$. Genus Rhizoctonia was not isolated in the variety K-28 while the K-22 was determined for $0.5 \%$. Presence of other fungi genera varied depending on the cultivars, the origin of the sample and the seed storage.

In method B, it can be seen that the six fungi genera isolated in both cultivars (K-22 and K-28) were: Fusarium (12.1 and 15.0\%), Alternaria (10.2 and 12.0\%), Rhizopus (0.5 and 3\%), Mucor (1 and 3\%), Penicilliium (1 and 1.1\%). 
Different was genus Aspergillus isolated in the variety K-22 (2\%). The difference was significant in health status of the seed between the methods.

\section{Discussion}

Many pathogens of alfalfa (Medicago sativa L.) that cause diseases of root and above-ground parts are usually transmitted by seed. Symptoms of the disease to manifest as rot, reduced germination, and wet rot before and after germination, seedlings decay, root and hypocotyl rot (Hancock, 1983). Infected seed does not germinate, or even if they germinate, seedlings are dying or give underdeveloped grown plants. The root or the stem initially has watery appearance, and later seedlings die (Krnjaja et al., 2005).

Fusarium spp is, for the most part, weak pathogen and cause little damage to vigorously growing plants. They do, however, penetrate and colonize healthy plants, whether they are wounded or not, and it appears that most alfalfa plants are infected with these fungi at very early age. The amount of damage resulting from the infection depends upon the physiologic condition of the host after infection. Probably any factor that weakness the host predisposes it to be damaged by these fungi (Krnjaja et al., 2003).

According to literature references Fusarium species could be considered as potential inducers of diseases in alfalfa. Mentioned species have proved their pathogenicity regarding the root of alfalfa and other hosts when inoculated at the tip of root. Isolates of Fusarium spp. constitute, majority, of the fungi isolated from alfalfa roots (up to $90 \%$ of all isolates), and isolates Alternaria spp., Penicillium spp., Mucor spp., Rhizopus spp., Trichoderma spp., Aspergillus spp., and the other species, followed in decreasing order of prevalence (Krnjaja et al., 2003).

Alfalfa seedlings are highly susceptible to Sclerotinia. Late summer or early fall seedlings are most vulnerable because plants are still in the seedling stage at the time of spore release, whereas spring seedlings will have passed the age of maximum susceptibility (Stuteville and Erwin, 1990).

Stemphylium leaf spot, a common foliar disease of alfalfa, may cause significant defoliation during warm wet periods in summer and fall. Foliar infection by Stemphylium reduces root growth and hastens death of alfalfa in the glasshouse, and some evidence indicates that similar effects occur in the field. The fungus Stemphylium botryousum is carried on seed (Stuteville and Erwin, 1990).

Obtained results indicate the significance of rinsing of seed (method B) to eliminate the presence of fungi on seed. This measure contributes to improvement of health condition of alfalfa seed. In practice, however, there is no example confirming the actual application of this or similar methods of preventive protection of seed from infection. One of the reasons is insufficient knowledge of 
the role of seed as carrier of some pathogen fungi that are important from the economical aspect, including species of Fusarium genus.

\title{
Conclusion
}

The species of genera Fusarium and Alternaria were present in all samples. The presence of other genera depends on sterilization length and origin of the sample.

Considering the significant differences in health state of seed by application of method $\mathrm{A}$ and method B, further investigations should be directed towards the development of methods which would show real health state of seed, that is, natural contamination of seed. In this case it is the use of method B.

\section{Acknowledgment}

Research was financed by the Ministry of Education and Science, Republic of Serbia, project TR 31057.

\section{Pojava i učestalost gljiva na semenu lucerke u Srbiji}

\author{
T. Vasić, B. Anđelković, S. Anđelković, S. Živković, D. Terzić, J. Milenković
}

\section{Rezime}

Lucerka je veoma značajna krmna biljka u našoj zemlji, mnogi je nazivaju i "kraljicom krmnih biljaka" jer zauzima značajno mesto $u$ ishrani stoke. Proizvodnja i dobijanje semena lucerke visokog kvaliteta je od primarnog značaja za stočarsku proizvodnju u Srbiji. Zaraze gljivama smanjuju kvalitet semena, a sve to utiče na prinose i kvalitet krme kao i na period iskorišćavanja lucerišta. Ispitivan je veći broj uzoraka semena lucerke poreklom iz: Srednje-Banatskog, Podunavskog, Niškog i Šumadijskog okruga. Uzorci su uzimani sa dve sorte lucerke K-22 i K-28.

$\mathrm{Na}$ osnovu proučavanja pojava gljiva na semenu lucerke utvrđeno je da se javljaju sledeće vrste: Fusarium spp., Alternaria spp., Stemphylium spp., Epiccocum spp., Nigrospora spp., Rhizopus spp., Mucor spp., Aspergillus spp. i Penicillium spp. Primarne su bile vrste iz rodova Fusarium i Alternaria, ostale vrste su bile zastupljene u različitim procentima. 


\section{References}

BURGESS L.W., SUMMERELL B.A., BULLOCK S., GOTT K.P., BACKHOUSE D. (1994): Laboratory manual for Fusarium reaserch. University of Sydney and Royal Botanic Gardens, Sydney.

CHI C.C., CHILDERS W.R., HANSON E.W. (1964): Penetration and subsequent development of three Fusarium species in alfalfa and red clover. Phytopathology, 54, 434-437.

GRAHAM J.H., DEVINE T.E., HANSON C.H. (1976): Occurrence and interaction of three species of Colletotrichum on alfalfa in the Mid-Atlantic United States. Phytopathology, 66, 538-541.

HANCOCK J.G. (1983): Seedling diseases of alfalfa in California. Plant Disease, 67, 1203-1208.

KRNJAJA V., IVANOVIĆ M., LEVIĆ J., TOMIĆ Z. (2005): Bolesti korena lucerke i mere suzbijanja. Biljni lekar/Plant Doctor, XXXIII, 5, 565-576.

KRNJAJA V., LEVIĆ J., IVANOVIĆ M., TOMIĆ Z. (2003): Fusarium species associated with seeds of alfalfa cultivars. Czech Journal of Genetics and Plant Breeding, 39, special issuse, 275-278.

KRNJAJA V., LEVIĆ J., IVANOVIĆ M., TOMIĆ Z., MRFAT-VUKELIĆ S. (2004): Incidence of Fusarium species on red clover seed. Biotehnology in Animal Hsbandry, 20, 1-2, 101-107.

NELSON P.E., TOUSSOUN T.A., MARASAS W.F.O (1983): Fusarium species, an illustrated manual for identification. Pennsylvania State University Press, Unervesity Park and London.

STUTEVILLE D.L., ERWIN D.C. (1990): Compendium of alfalfa diseases, second edition.The American Phytopathological Society St. Paul, Minnesota.

WATANABE T. (1994): Pictorial atlas of soil and seed fungi. Morphologis of cultured fungi and key to species. Lewis Publishers. Boca Raton. 